ELORE (ISSN 1456-3010), vol. 19 - 1/2012.

Julkaisija: Suomen Kansantietouden Tutkijain Seura ry.

[http://www.elore.fi/arkisto/1_12/haapoja.pdf]

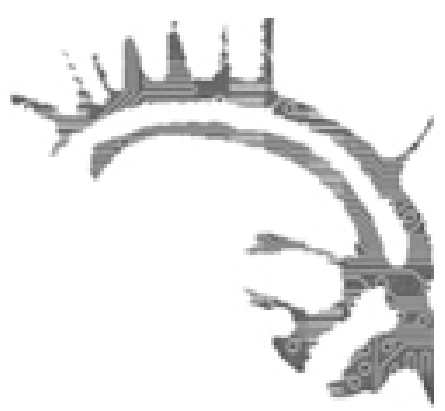

\title{
KIRJA-ARVIO
}

\section{JA NIIN SYNTYI SUOMIETNO}

HEIKKILÄ, JOHANNES \& VIRTANEN, HANNU 2011: Pilven piirtä myöten. Suomietnon synty. Helsinki: SKS. 368 sivua.

\section{Heidi Haapoja}

Suomalainen nykykansanmusiikki on teema, josta on pitkään kaivattu kattavaa suomenkielistä yleisesitystä tai muuta kirjallista kuvausta. Aihetta on sivuttu aiemmin siellä täällä yksittäisissä opinnäytetöissä tai suomalaisen populaarimusiikin historiaa käsittelevissä teoksissa, mutta juuri kyseiseen teemaan keskittyvää julkaisua ei ole ollut saatavilla. Suomalaisen Kirjallisuuden Seura on vastannut tähän tarpeeseen julkaisemalla Pilven piirtä myöten -tietokirjan, joka käsittelee suomietnon vaiheita 1960-luvulta 1990-luvun alkuun asti.

Suomietnolla viitataan kirjan yhteydessä musiikkigenreen, jota nykyään usein kutsutaan nykykansanmusiikiksi. Sen ominaispiirteitä ovat perinteisiin sävel- tai tekstiaineksiin nojaaminen, fuusiot muiden musiikinlajien kanssa, estradiesiintymiset sekä luova ja improvisoiva lähestymistapa musiikin tekemiseen. Rajanvedot genren erilaisten nimitysten välillä ovat hiuksenhienoja, mutta suomietno-sanan avulla kirjan aihepiiriä on laajennettu hivenen kansanmusiikki-päätteisten ilmaisujen yleisten merkitysten ulkopuolelle: sana etno ymmärretään usein hieman laajemmin, ja sen sisään voitaneen kattaa esimerkiksi maailmanmusiikki-ilmiöt sekä kirjan tapauksessa myös kansanmusiikista vaikutteita saanut folk ja jazz.

Pilven piirtä myöten -teos lähestyy aihettaan esittelemällä kronologisesti bändejä, artisteja ja genren taustalla vaikuttaneita henkilöitä. Kirjan tyyli on jutusteleva, artisteja kutsutaan etunimellä ja tekstissä on viljelty runsaasti henkilöihin liittyviä anekdootteja. Tämä selittynee kirjan tekijöiden ilmeisen läheisillä suhteilla haastateltaviin ja yleisesti 
Heidi Haapoja: Ja niin syntyi suomietno

koko kenttään. Teoksen lähtökohta on ehkä hivenen insider-henkinen, mutta kirjan helposti lähestyttävä ominaistyyli tarjonnee kuitenkin myös ulkopuoliselle aiheesta kiinnostuneelle tarttumapintaa. Anekdoottimainen lähestymistapa on kuitenkin huomioitava lukukokemuksen avautumisen helpottamiseksi: kirjaa on luettava muistelmallisena aikalaiskuvauksena. Tieteellistä analyysia kirja ei tarjoa, mutta on arvokas sinänsä muistelma-aineistona. Teosta varten on haastateltu useita eturivin muusikoita ja muita suomalaisen musiikkielämän vaikuttajia.

Osansa kirjassa saavat sellaiset kuuluisat nimet kuten Piirpauke, Nils-Aslak Valkeapää, Martti Pokela ja Värttinä, mutta näiden rinnalle on nostettu myös unholaan vaipuneita yhtyeitä ja artisteja esimerkiksi suomalaisen folkin tai poliittisen laululiikkeen piiristä. Kirjassa tarkastellaan jonkin verran myös 1960- ja 1970-lukujen suomalaista musiikkikenttää laajemmin ja esitellään muutama kansanmusiikkiaineksista vaikutteita saanut klassinen nykymusiikki- ja kuoroteos. Teoksessa on esillä suhteellisen paljon ennen julkaisemattomia mustavalkoisia kuvia, ja kirjan keskiosassa on värikuvaliite, johon on koottu keskeisten suomietnolevyjen kansitaidetta. Liite on varsin vaikuttava: genren levykansissa vilahtelevat niin ikoniset tuohivirsut, Väinämöiset, hanurit, kalliomaalaukset, järvimaisemat, Karjala-viittaukset kuin graafisemmat ja abstraktimmat 1970-luvun poptaidevaikutteetkin.

\section{UUTTA NYKYKANSAN MUSIIKKIA}

Kansanmusiikkialan tutkijan näkökulmasta teoksen kiinnostaviksi elementeiksi nousevat yhteiskunnallisen, poliittisen, etnomusikologisen ja koulutuspoliittisen ilmapiirin kuvailu kansanmusiikin perspektiivistä. 1960-1970-lukujen yhteiskunnallinen ilmapiiri heijastui vahvasti kansanperinteen harrastamiseen ja esilletuontiin. Kansallista tietoisuutta haluttiin rakentaa kylmän sodan varjosta huolimatta ja tähän kansanmusiikki oli oiva väline. Lisäksi puoluepolitiikassa oltiin sekä vasemmalla että oikealla laidalla kiinnostuneita kansanmusiikin hyödyntämisestä. Kansanmusiikin harjoittaminen tai kuunteleminen vetosi myös monen suomalaisen sieluun yhteiskunnassa tapahtuneen suuren murroksen, kaupungistumisen ja teollistumisen vuoksi. Moni kaipasi vanhoihin aikoihin, mutta kaipauksen kohteena ei ollut niinkään maaseudun konkreettiseen elinympäristöön raskaine töineen, vaan haikeus kohdistui nimenomaan maalaiskulttuuriin, talonpoikaisiin arvoihin. Varsinkin maalta kaupunkeihin muuttaneet kokivat kaupungistumisprosessin kivuliaana, sillä maalaiskulttuurin arvot eivät sopineet uusiin elinolosuhteisiin. Tällöin kansankulttuuriharrasteet tarjosivat monelle väylän kanavoida kaipuutaan. Pilven piirtä myöten nostaa esille muun muassa erilaiset kansanmusiikin instituutiot, jotka syntyivät pääosin 1970-luvulla vastaamaan yhteiskunnan ja toisaalta myös kansanperinnenälkäisten ihmisten tarpeeseen.

On mielenkiintoista lukea Pilven pïrtä myöten -teosta pitäen silmällä sitä, miten suomietno nähdään kansanperinteentutkimuksen kartalla. Onko se osa perinteen jatkumoa systemaattisella kansanmusiikin janalla? Onko kyseessä niin sanotusti elvytetty ilmiö tai kenties kansanperinteen uudelleentulkintaa, reproduktiota? Kirjasta 
on löydettävissä puheenvuoroja erilaisten tulkintojen tueksi, mutta kirjoittajat tekevät ainakin esipuheessa selkeän jaon perinteisen kansanmusiikin ja suomietnon välille:

[..] perinteinen kansanmusiikki - vaikka sekin on toki koko ajan uudistuvaa - on tällä kertaa sivuroolissa. [..] Kirjassamme lähestytäänkin aihetta ennen kaikkea mukana olevien haastateltavien ja heidän musiikillisten elämänkaariensa kautta. Olemme nostaneet esiin henkilöitä ja kokoonpanoja, jotka ovat käyttäneet musiikissaan uudella tavalla aineksia suomalaisesta tai suomalais-ugrilaisesta kansanmusiikkiperinteestä. Kyse voi olla sävelmästä, laulurunoudesta, soittimista tai tyylistä - musiikin hengestä. Lisäksi mukana voi olla vaikutteita populaarimusiikista, muista etnisistä musiikkiperinteistä tai ihan mistä tahansa. (s. 8-9.)

Kirjan pääpaino tuntuu olevan siis eräänlaisessa uudentamisessa, modernissa otteessa. Nykyisyys ja musiikki ovat mitä ilmeisimmin kirjoittajille ja myös haastateltaville tärkeämmässä roolissa kuin "kansa" tai suomalaisuus. Kansanomaisuus on viitteellinen käsite, jonka voidaan tulkita viittaavan enemmän vanhaan kansaan, entisajan ihmisiin kuin kansakuntaan.

\section{MÄNIN PILVEN PIIRTÄ MYÖTEN}

Millaista dialogia suomietno käy esimerkiksi sadanviidenkymmenen vuoden takaisen kansanmusiikkiaineiston ja -kulttuurin kanssa? Kuten yllä olevasta lainauksesta voi todeta, perinneaineksiin nojaaminen voi olla genren sisällä varsin viitteellistä. Ilmiönä tällainen suhtautuminen kansanperinteeseen on mielenkiintoinen ja herättää kysymyksiä. Ajatukset perinteen autenttisuudesta tai erityisesti autenttisuuteen pyrkimisestä ovat aikansa eläneitä tämän ilmiön kohdalla, joten näkökulma sen tarkasteluun tulee olla toinen. Käsillä oleva teos ei tarjoa valmiita ratkaisuja tällaiseen uuteen perspektiiviin, mutta tarjoaa hedelmällistä materiaalia analyysin avuksi.

Kirjan nimi kuvailee suomietnoa genrenä mainiosti. Pilven piirtä myöten viittaa kalevalamittaiseen säkeeseen (mänin pilven piirtä myöten), muttei kuitenkaan noudata klassista runomittaa. Tyngän runosäkeen voi tulkita viittaavan taivaiden tavoittelemiseen, ehkä maineen saavuttamiseen. Toisaalta säe voi kuvata sitä, että genren luovuuden rajana on vain taivas. Alaotsikko Suomietnon synty taas on sommiteltu samaan tyyliin kuin Suomen Kansan Vanhoissa Runoissa joillekin runoteksteille annetut otsakkeet "Maailman synty", "Veneen synty" ja niin edelleen. Syntyrunot kertovat useimmiten alusta, ensimmäisestä, syntymisestä. Suomietno genrenä viittaa vanhaan, mutta samaan aikaan on täysin uusi, ensimmäinen.

Filosofian maisteri, musiikin kandidaatti Heidi Haapoja tekee väitöskirjaa suomalaisesta nykyrunolaulusta Helsingin yliopistossa folkloristiikan oppiaineessa. 